\title{
Effect of Different Sources of Organic Manures and Seed Biopriming on Growth and Nutrient Uptake of Rice Bean (Vigna umbellate)
}

\author{
Pratima Ningaraddi Morab*, G. Gangadhar Eswar Rao and Roopa K. Muttappanavar
}

Department of Agronomy, UAS, GKVK, Bangalore, India

RIOF, UAS, GKVK, Bangalore, India

*Corresponding author

\section{Keywords}

Rice bean, Bio-priming

Article Info

Accepted:

15 December 2020

Available Online:

10 January 2021
A field experiment was conducted during kharif-2019 at Research Institute of Organic Farming field unit, UAS, GKVK, Bengaluru to study the Effect of different sources of organic manures and seed bio-priming on growth and yield of rice bean (Vigna umbellate) laid out in Factorial Randomized Complete Block Design with 10 treatments replicated thrice and the variety used was KBR-1. Results of the experiment revealed that seed biopriming with Rhizobium and Trichoderma recorded significantly higher growth parameters like plant height $(89.20 \mathrm{~cm})$, branches per plant $(8.63)$, leaf area $(767.52 \mathrm{~cm} 2$ plant-1), dry matter production per plant $(23.79 \mathrm{~g})$, number of nodules per plant $(48.27)$ and nutrient uptake nitrogen $\left(80.7 \mathrm{~kg} \mathrm{ha}^{-1}\right)$, phosphorous $\left(19.03 \mathrm{~kg} \mathrm{ha}^{-1}\right)$ and potassium (72.29 $\left.\mathrm{kg} \mathrm{ha}^{-1}\right) 100 \% \mathrm{~N}$ equivalent through vermicompost recorded significantly higher growth parameters like plant height $(90.17 \mathrm{~cm})$, branches per plant $(10.30)$, leaf area $(847.09 \mathrm{~cm} 2$ plant-1), dry matter production per plant $(26.30 \mathrm{~g})$, number of nodules per plant (42.83) and nitrogen $\left(84.21 \mathrm{~kg} \mathrm{ha}^{-1}\right)$, phosphorous (18.23 kg ha $\left.{ }^{1}\right)$ and potassium $\left(65.83 \mathrm{~kg} \mathrm{ha}^{-1}\right)$.

\section{Introduction}

Rice bean (Vigna umbellate), a member of the leguminosae (Fabaceae) family, is an annual underutilized grain legume or pulse is native of south East Asia. It is newly introduced crop in Karnataka and is commonly known as redbean, Mambi bean, climbing mountain bean, Japanese rice bean, bamboo bean and oriental bean and considered as a potential grain legume because of its high protein content. In India, Rice bean is used for both food and fodder. Legumes in general are scarce, costly and defective in their nutritional and cooking qualities but rice bean seed protein is varies from 15-25 per cent.Rice bean has drawn special attention due to its high seed yield $\left(22-25 q \mathrm{ha}^{-1}\right)$. It is fairly drought tolerant and grows well on relatively poor soils. It has wider adoptability to different agro-ecologies and is highly resistant to viral diseases. Varieties and land races 
grow profusely, spreading and twinning type, with immediate growth. It is very sensitive to day length. Flowering and pod setting are initiated with the onset of short days (Singh and Tomer, 1989).

Bio-priming is a new promising technique of seed treatment that integrates biological and physiological method of improving plant growth and controlling disease. It is recently used as an alternative method for controlling many seed and soil borne pathogens. Thus, considered as an advanced technique of seed treatment which includes of application of beneficial microorganism on seed surface and seed hydration (Singh etal., 2016).

\section{Materials and Methods}

A field experiment was conducted during kharif 2019 at organic farming research and demonstration field unit (J block) of Research Institute on Organic Farming (RIOF), Gandhi KrishiVignan Kendra (GKVK), University of Agricultural Sciences, Bengaluru, to study the Effect of different organic manures and seed bio-priming on growth and yield of rice bean consisted of ten treatments replicated thrice in FRCBD. The soil was red sandy clay loam andthe treatments tested where $\mathrm{T}_{1}$ : without seed biopriming, $\mathrm{T}_{2}$ : with seed biopriming, $\mathrm{T}_{3}: 100 \% \mathrm{~N}$ equivalent through $\mathrm{FYM}+$ seed biopriming, $\mathrm{T}_{4}: 100 \% \mathrm{~N}$ equivalent through Vermicompost +seed biopriming, $\mathrm{T}_{5}: 100 \% \mathrm{~N}$ equivalent through Neemcake + seed biopriming, $\quad \mathrm{T}_{6}: 100 \% \mathrm{~N}$ equivalent throughbiodiegester liquid organic manure +seedbiopriming, $\quad \mathrm{T}_{7}: 100 \% \mathrm{~N}$ equivalent through FYM +without seedbiopriming, $\mathrm{T}_{8}$ : $100 \% \mathrm{~N}$ equivalent through Vermicompost+ without seedbiopriming, $\mathrm{T}_{9}: 100 \% \mathrm{~N}$ equivalent through Neemcake+ without seedbiopriming, $\mathrm{T}_{10}: 100 \% \mathrm{~N}$ equivalent through biodigester liquid organic manure + without seed bioprimming. RDF:40:20:20, basal dose application of FYM @ $10 \mathrm{tha}^{-1}$ to all treatments except $\mathrm{T}_{1}$ and $\mathrm{T}_{2}$. Variety KBR-
1 was sown at a spacing of $45 \mathrm{~cm} \times 10 \mathrm{~cm}$, gross and net plots size was $4.5 \mathrm{~m} \mathrm{x} 3.5 \mathrm{~m}$ and $2.7 \mathrm{~m}$ x $3.1 \mathrm{~m}$ respectively.

\section{Seed bio-priming (seed treatment)}

Pre-soaked the seeds in water for $12 \mathrm{hrs}$ then mixed the formulated product of bio-agents (Rhizobium and Trichoderma) with presoaked seeds at the rate of $10 \mathrm{~g}$ per $\mathrm{kg}$ of seeds with adhesive material castor oil (100 $\mathrm{ml}$ per $\mathrm{kg}$ seeds) and put the treated seeds as a heap then covered the heap with moist jute sack to maintain high humidity. Then kept for incubation under high humidity for about 48 hrs approximately 25-32 per cent. Bio-agents adhered to the seed grows on the seed surface under moist condition to form a protective layer all around the seed coat.

Data on rice bean grain and stover yield collected after harvest of the crop and averaged over three replications. The data collected on different trait was statistically analysed using standard procedure and the results were tested at the five percent level of significance as given by Gomez and Gomez (1984).

\section{Uptake of $\mathbf{N}, \mathbf{P}$ and $\mathrm{K}$}

Uptake of Nitrogen, Phosphorous and Potassium were calculated by using the following formula and expressed in $\mathrm{kg} \mathrm{ha}^{-1}$

$$
\text { Nutrient content }(\%) \times
$$

Nutrient uptake Biomass of fruit/stalk $(\mathrm{kg}$ $\left(\mathrm{kg} \mathrm{ha}^{-1}\right)=$

$\frac{\left.\mathrm{ha}^{-1}\right)}{100}$

\section{Results and Discussion}

Growth parameters of rice bean were recorded significantly higher due to seed biopriming with Rhizobium and Trichodermalike plant height $(89.20 \mathrm{~cm})$, branches per plant (8.63), leaf area (767.52 cm2 plant-1), dry 
matter production per plant(23.79 g), number of nodules per plant (48.27). This is due to bio-primed seed showed higher germination and better plant growth added advantage of con-trolling seed and soil borne pathogens and plant growth promoting effects. Enhancement in seedling emergence and growth parameters was observed higher in $\mathrm{W}_{1}$ (with seed bio-priming) because of the fact that Rhizobium and PGPR share a common microhabitat, the root soil inter surface, where interactions between different microbial groups (Yadav et al., 2013).

Growth parameters recorded higher with $100 \% \mathrm{~N}$ equivalent through Vermicompost, plant height $(90.17 \mathrm{~cm})$, branches per plant (10.30), leaf area $(847.09 \mathrm{~cm} 2$ plant-1), dry matter production per plant(26.30 g), number of nodules per plant (42.83). This is because of increase in growth parameters through organic nutrient management might be due to enhanced uptake of $\mathrm{N}, \mathrm{P}$ and $\mathrm{K}$, which results in better vegetative growth, root growth and productive ability of the rice bean. Vermicompost added a good amount of NPK in the soil, besides supplying other essential micronutrients and also it includes plant growth regulators which increase the growth and yield. Excreta of earthworms contain large amounts of plant hormones (auxin, gibberline, and cytokynine) which also affects the plant growth and development (Zahedifard et al., 2014).

Table.1 Growth parameters of rice bean as influenced by different organic sources and seed biopriming

\begin{tabular}{|c|c|c|c|c|c|}
\hline & $\begin{array}{c}\text { Plant } \\
\text { height }\end{array}$ & $\begin{array}{c}\text { No. of } \\
\text { branches } \\
\text { plant }^{-1}\end{array}$ & $\begin{array}{c}\text { Leaf } \\
\text { area } \\
\left(\mathrm{cm}^{2}\right. \\
\left.\text { plant }^{-1}\right)\end{array}$ & $\begin{array}{c}\text { Dry } \\
\text { matter } \\
\text { production } \\
\text { per plant } \\
\left(\text { g plant }^{-1}\right)\end{array}$ & $\begin{array}{c}\text { No. of } \\
\text { nodules } \\
\text { per } \\
\text { plant }\end{array}$ \\
\hline \multicolumn{6}{|l|}{ A. Seed bio-priming } \\
\hline $\begin{array}{l}W_{1} \text { (With seed bio- } \\
\text { priming) }\end{array}$ & 89.20 & 8.63 & 767.52 & 23.79 & 48.27 \\
\hline $\begin{array}{l}\mathrm{W}_{2} \text { ( Without seed } \\
\text { bio-priming) }\end{array}$ & 80.37 & 8.56 & 715.94 & 21.47 & 27.20 \\
\hline F- test & $*$ & $*$ & $*$ & $*$ & $*$ \\
\hline S.Em \pm & 1.65 & 0.16 & 16.384 & 0.549 & 1.17 \\
\hline$C D(p=0.05)$ & 4.91 & 0.49 & 48.680 & 1.630 & 3.47 \\
\hline \multicolumn{6}{|l|}{ B. Organic sources } \\
\hline$S_{1}-$ control & 76.25 & 7.08 & 418.95 & 19.88 & 20.67 \\
\hline $\mathbf{S}_{2}-\mathbf{F Y M}$ & 83.33 & 7.87 & 727.71 & 22.33 & 42.7 \\
\hline$S_{3}-$ Vermicompost & 90.17 & 10.30 & 847.09 & 26.30 & 42.83 \\
\hline $\mathrm{S}_{4^{-}}$Neem cake & 88.50 & 9.67 & 764.16 & 22.35 & 41.50 \\
\hline $\mathbf{S}_{5}-\mathbf{B D L M}$ & 85.67 & 8.06 & 750.17 & 22.27 & 41.00 \\
\hline F- test & $*$ & $*$ & $*$ & $*$ & $*$ \\
\hline S.Em \pm & 2.617 & 0.26 & 25.906 & 0.86 & 1.85 \\
\hline $\mathrm{CD}(\mathrm{p}=\mathbf{0 . 0 5})$ & 7.78 & 0.78 & 76.97 & 2.58 & 5.50 \\
\hline
\end{tabular}


Table.2 Nutrient uptake of rice bean as influenced by different organic sources and seed biopriming

\begin{tabular}{|c|c|c|c|}
\hline Treatment & $\begin{array}{c}\text { Nitrogen } \\
\left(\mathrm{kg} \mathrm{ha}^{-1}\right)\end{array}$ & $\begin{array}{l}\text { Phosphorus } \\
\left(\mathrm{kg} \mathrm{ha}^{-1}\right)\end{array}$ & $\begin{array}{c}\text { Potassium } \\
\left(\mathrm{kg} \mathrm{ha}^{-1}\right)\end{array}$ \\
\hline \multicolumn{4}{|l|}{ A. Seed bio-priming } \\
\hline \multicolumn{4}{|l|}{ A. Seed bio-priming } \\
\hline $\mathrm{W}_{1}$ (With seed bio-priming) & 80.7 & 19.03 & 72.79 \\
\hline $\mathrm{W}_{2}$ (Without seed bio-priming) & 70.25 & 17.00 & 62.10 \\
\hline F- test & $*$ & $*$ & $*$ \\
\hline S.Em \pm & 1.807 & 0.540 & 1.831 \\
\hline $\mathrm{CD}(\mathrm{p}=\mathbf{0 . 0 5})$ & 5.370 & 1.605 & 5.439 \\
\hline \multicolumn{4}{|l|}{ B. organic sources } \\
\hline$S_{1}-$ control & 25.20 & 8.76 & 44.71 \\
\hline $\mathbf{S}_{2}-\mathbf{F Y M}$ & 77.59 & 16.77 & 62.31 \\
\hline $\mathbf{S}_{3}$-Vermicompost & 108.34 & 27.97 & 99.65 \\
\hline $\mathrm{S}_{4}$ - Neem cake & 84.21 & 18.23 & 65.83 \\
\hline $\mathbf{S}_{5}-\mathbf{B D L M}$ & 82.15 & 18.32 & 64.74 \\
\hline F- test & $*$ & $*$ & $*$ \\
\hline S.Em \pm & 2.85 & 0.85 & 2.89 \\
\hline $\mathrm{CD}(\mathrm{p}=\mathbf{0 . 0 5})$ & 8.49 & 2.55 & 8.67 \\
\hline
\end{tabular}

Nutrient uptake of rice brean crop was observed significantly higher due to seed biopriming with Rhizobium and Trichoderma. Nitrogen (80.7 $\left.\mathrm{kg} \mathrm{ha}^{-1}\right)$, phosphorous (19.03 $\mathrm{kg} \mathrm{ha}^{-1}$ ) and potassium (72.29 $\left.\mathrm{kg} \mathrm{ha}^{-1}\right)$.biopriming is directly involved in the enhancement of plant growth by the secretion of compounds and mineral solubilisation (Mirshekariet al., 2012).

Nutrient uptake of rice brean crop was recorded significantly higher with $100 \% \mathrm{~N}$ equivalent through vermicompost. This is because ofvermicompost provides readily available forms of nutrients to plants and increase the uptake (Singh et.al 2012; Grantina-Ievinaet al., 2015). Improved physical conditions of the soil which support better aeration to plant root, drainage of water, facilitation of cations $\mathrm{N}^{+} \mathrm{P}^{+}$and $\mathrm{K}^{+}$ exchange, sustained availability of nutrients, and thereby the uptake by the plants resulting in better growth and yield (Manivannanet al., 2009).

In conclusion, seed bio-priming with Rhizobium and Trichodermaand 100\% N equivalent through vermicompost resulted in better growth of rice bean crop and nutrient (N, P and K) uptake by the crop compared to control.

\section{References}

Gomez, KA. and Gomez, AA. Statistical procedures agricultural research, an international rice research institute book, A Willey Inter Science Publication, John Willey and Sons, New York. 1984.

Grantina-Ievina, L., Nikolajeva, V., Rostoks, N., Skrabule, I., Zarina, L., Pogulis, A., Ievinsh, G., Impact of green manure and vermicompost on soil 
suppressiveness, soil microbial populations and plant growth in conditions of organic agriculture of Northern temperate climate.Organic Amendments and soil Suppressiveness in Plant Disease Management. 2015, 381-399.

Mehdi Zahedifard, Shahram Sharfzadeh, Mokhtar Zolfibavarian, and Mahdi Zare, Influence nitrogen and vermicompost on grain and oil yield of Rapeseed. Bull. Env. Pharmacol. Life Sci., 2014,3(7): 54-57.

Mirshekari, B., Hokmalipour, S. and Sharifi, RS.,2012, Effect of seed bio-priming with plant growth promoting rhizobacteria (PGPR) on yield and dry matter accumulation of spring barley (Hordeum vulgare L.) at various levels of nitrogen and phosphorus fertilizers. $J$ Food Agric Environ10:314-20.

Manivannan, S., Balamurugan, M., Parthasarathi, K., Gunasekaran, G., and Ranganathan, LS., Effect of vermicompost on soil fertility and crop productivity - beans (Phaseolus vulgaris). J. Environ. Biol.2009,
30(2): 275-281.

Singh, VP., and Tomer, YS., Breeding of neglected and underutilized crops, spices and herbs. J. of legume Res. 1989,12(1):47.

Singh, R., Soni, SK., Awasthi, A., and Kalra, A., Evaluation of vermicompost doses for management of root-rot disease complex in Coleus forskohlii under organic field conditions. Australasian Plant Pathology. 2012, 41: 397-403.

Singh, V., Upadhyay, RS., Sarma, BK. and Singh, HB., Seed bio-priming with Trichoderma asperellum effectively modulate plant growth promotion in pea. Int. J. Agri. Environ. Biotechnol. 2016, 9: 361-365.

Yadav, BN., Syam Sundar Reddy, P., Syed Sadarunnisa, Srinivasarao, G., Deepthi Kiran, Y. and Ramanjaneyareddy, A., Root yield and nutrient uptake of Radish (Raphanus sativus L.) as influenced by the application of organic and inorganic sources of nitrogen and their combinations. Int. J. Chem. Stud., 2018,6(4): 3116-3119.

\section{How to cite this article:}

Pratima Ningaraddi Morab, G. Gangadhar Eswar Rao and Roopa K. Muttappanavar. 2021. Effect of Different Sources of Organic Manures and Seed Biopriming on Growth and Nutrient Uptake of Rice Bean (Vigna umbellate). Int.J.Curr.Microbiol.App.Sci. 10(01): 2363-2367. doi: https://doi.org/10.20546/ijcmas.2021.1001.273 